\title{
Ontogenic changes in the contents of dopamine, norepinephrine and serotonin in larvae and postlarvae of the bivalve Pecten maximus
}

\author{
Christine Cann-Moisan ${ }^{\mathrm{a}, *}$, Laurence Nicolas ${ }^{\mathrm{b}}$, René Robert ${ }^{\mathrm{b}}$ \\ ${ }^{a}$ Service de Physiologie, Faculté de Médecine, Université de Bretagne Occidentale, 22, avenue Camille Desmoulins, 29285 Brest cedex, France \\ ${ }^{\mathrm{b}}$ Laboratoire de Physiologie des Invertébrés Marins, Ifremer, Écloserie Expérimentale d'Argenton, Presqu'île du Vivier, 29840 Landunvez, France
}

Received 8 April 2002; accepted 29 August 2002

\begin{abstract}
In the present study, norepinephrine (NE), epinephrine (E), dopamine (DA) and 5-hydroxy-tryptamine (5HT) have been quantified by high performance liquid chromatography (HPLC) in Pecten maximus during larval and post-larval development. With average values ranging from 2 to $5 \mathrm{pg} \mathrm{\mu g}^{-1}$ of protein, NE remained low through the whole larval life, while epinephrine (E) was undetected. DA and 5HT were the most abundant monoamines with significant variations between larval, pre-metamorphic and post-larval stages. During the first 20

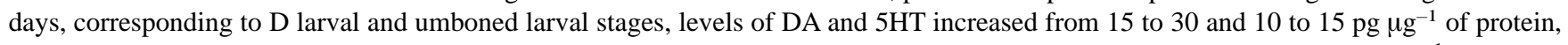
respectively. Then during the last week of larval life, at the approach of metamorphosis, DA rose sharply from 30 to $50 \mathrm{pg}^{\mathrm{g}} \mathrm{g}^{-1} \mathrm{of}_{\mathrm{protein}}$ and $5 \mathrm{HT}$ from 15 to $50 \mathrm{pg} \mathrm{\mu g}^{-1}$ of protein. Lastly during the first week of post-larval life (day 27 to day 34) DA and 5HT contents declined

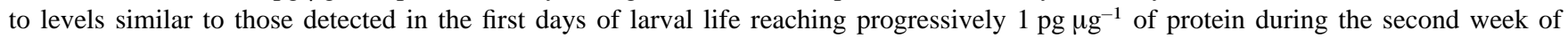
post-larval life (day 34 to day 55). These rapid and transient variations in monoamine contents (5HT and DA) around metamorphosis, present a great interest. However, this relation between neurochemical changes and metamorphosis must be confirmed with future studies in order to verify if such monoamines might be used as indicators of larval competence in P. maximus, a commercially important species. (C) 2002 Ifremer/CNRS/Inra/IRD/Cemagref/Éditions scientifiques et médicales Elsevier SAS. All rights reserved.
\end{abstract}

\section{Résumé}

Évolution ontogénique des teneurs en dopamine, adrénaline et sérotonine chez les larves et post-larves du bivalve Pecten maximus. L'évolution des teneurs en noradrénaline, adrénaline, dopamine et sérotonine a été étudiée en phase larvaire et post-larvaire chez la coquille St-Jacques Pecten maximus. Avec des valeurs moyennes (déterminées par HPLC) comprises entre 2 et $5 \mathrm{pg}^{\mathrm{g}} \mathrm{g}^{-1} \mathrm{de}$ protéine, la noradrénaline fluctue peu tandis que l'adrénaline n'a pu être détectée quel que soit le stade considéré, larvaire ou post-larvaire. La dopamine et la sérotonine étaient particulièrement abondantes et présentaient des variations significatives entre les phases larvaire, pré-métamorphique et post-larvaire. Au cours des 20 premiers jours, correspondant aux stades larves D puis umbonées, les teneurs en dopamine et sérotonine

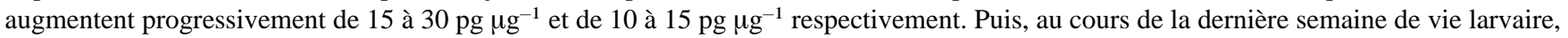
à l'approche de la métamorphose, la teneur en dopamine augmente brusquement de 30 à $50 \mathrm{pg}^{-1} \mathrm{~g}^{-1}$ et celle de la sérotonine de 15 à

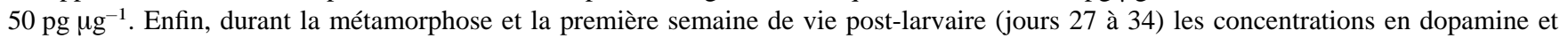
sérotonine chutent jusqu'à des valeurs similaires à celles détectées en début de vie larvaire et atteignent, au cours de la deuxième semaine

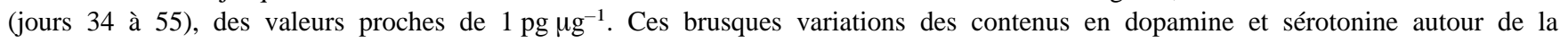
métamorphose présentent un réel intérêt. Cependant, cette relation entre les modifications neurochimiques et la métamorphose doit être affinée par des études complémentaires avant de confirmer que les amines biogènes peuvent être utilisées comme indicateur de compétence larvaire à la métamorphose chez Pecten maximus. (C) 2002 Ifremer/CNRS/Inra/IRD/Cemagref/Éditions scientifiques et médicales Elsevier SAS. Tous droits réservés.

Keywords: Monoamines; Larvae; Post-larvae; Metamorphosis; Pecten maximus

\footnotetext{
* Corresponding author.

E-mail address: christine.moisan@univ-brest.fr (C. Cann-Moisan).
} 


\section{Introduction}

Monoamines such as norepinephrine (NE), epinephrine (E), dopamine (DA) and 5-hydroxy-tryptamine (5HT) are major neurotransmitters in vertebrates and their roles in many physiological processes are now well established (Weiner and Molinoff, 1989).

These neuroactive compounds have been isolated from different tissues of marine invertebrates such as molluscs (Martinez et al., 1996; Pani and Croll 1995; Pires et al., 1997). More recently, catecholamines have also been detected by high performance liquid chromatography (HPLC) in the hemolymph of Placopecten magellanicus (Pani and Croll, 2000) while catecholaminergic neurons were located by histochemistry not only in the central nervous system, gills ganglia and gonads of this species (Smith et al., 1998) but also in the velum and foot of mussel and scallop larvae (Croll et al., 1997). In parallel, serotoninergic neurons that regulate ciliary activity have been located in molluscan embryos (Kuang and Goldberg, 2001). These different investigations suggest that the monoamines may be involved in physiological processes like reproduction, feeding, respiration, and locomotion. For example, variations of catecholamine contents have been correlated with spawning in bivalves (Osada et al., 1987; Paulet et al., 1993). On the other hand, larval settlement has been induced with such neurotransmitters, analogues or precursors in oysters (Coon and Bonar, 1985; Shpigel et al., 1989; Bonar et al., 1990; Beiras and Widdows 1996) and scallop (Yvin et al., 1985; Chevolot et al., 1991; Nicolas et al., 1998).

Although hatchery techniques are now mastered, the rearing of Pecten maximus larvae and post-larvae is highly variable in terms of both growth and survival. Thus, the larval capacity to undergo metamorphosis is considered to be of primordial importance, as this factor alone may be responsible for the highly fluctuating post-larval rearing yields, which may range from 20 to $60 \%$ (Nicolas and Robert, 2001). A previous study showed the importance of morphological (double-ring) and biochemical aspects (lipid content) in pediveligers for the success of metamorphosis. These two combined parameters, which explained $50 \%$ of the total metamorphosis variance, are used as indicators of larval competence for $P$. maximus metamorphosis (Robert et al., 1999).

In an attempt to identify other possible endogenous markers, the kinetics of monoamines (NE, E, DA, 5HT) were examined, in the present study, throughout larval and post-larval development in $P$. maximus.

To our knowledge, it is the first time that such results, determined by HPLC, are reported in this bivalve species.

\section{Materials and methods}

\subsection{Chemical sources}

Monoamine standards and sodium octyl sulfate were purchased from Sigma Chemical Co. (St. Louis, MO).
HPLC grade perchloric acid, acetic acid, acetonitrile, butanol, heptane and potassium carbonate, ammonium formate were obtained from Merck (Darmstadt, Germany). Boric acid gel was purchased from Biorad laboratory (Richmond, CA).

\subsection{Larval and post-larval cultures}

Three different larval batches issued from different spawnings were run to determine the contents of biogenic amines in larvae and post-larvae.

The larval and post-larval rearing techniques for $P$. maximus have been previously described (Robert and Gérard, 1999; Nicolas and Robert, 2001). After 2 days of incubation, the $\mathrm{D}$ larvae were distributed at a density of seven larvae per $\mathrm{ml}$, in 4501 conical-cylindrical tanks. The seawater $\left(18^{\circ} \mathrm{C}\right.$, $34 \mathrm{ppt}$ ) was $1 \mu \mathrm{m}$ filtered and renewed every second day. The bacterial proliferation was controlled by addition of chloramphenicol at $4 \mathrm{mg} \mathrm{l}^{-1}$. The food ration consisted of a three-species mixed called PTS: 1/3 Pavlova lutheri, 1/3 Isochrysis affinis galbana (T. iso) and 1/3 Skeletonema costatum (v/v).

After filtration through a $150 \mu \mathrm{m}$ sieve (larval length $\geq 220 \mu \mathrm{m}$ ), the pediveligers were transferred in the micronursery at a density of $3 \mathrm{ml}^{-1}$ in 11 cylindrical chambers with a $125 \mu \mathrm{m}$ nylon meshed base. Each chamber was suspended $10 \mathrm{~mm}$ from the base of a 1001 flat-bottom tank and continuously supplied with $1 \mu \mathrm{m}$ filtered seawater enriched with phytoplankton by a "down welling system".

Three different batches have been followed from day 2 to day 55. Each larval population has been sampled every second to fourth day. Twenty thousand larvae (counted under a profile projector Nikon V12) were collected and sampling duplicated. After grading, they were stored in Eppendorf tubes in liquid nitrogen until extraction procedure for monoamines (1 month maximum).

During the post-larval rearing, sampling, performed once a week, was based on the whole populations (larvae ready to metamorphose and post-larvae) removed from three chambers. The metamorphosis rate was determined from a population issued from one chamber by counting the number of individuals exhibiting post-larval shell under a profile projector, while two other populations were collected and stored until extraction procedure as previously described with larvae.

\subsection{Extraction procedures}

Samples of larvae $(n=20000)$ and post-larvae $(n=3000)$ were homogenized with ultrasound in $5 \mathrm{ml}$ of perchloric acid (5\%) containing two internal standards (125 ng of 5-hydroxymethyltyramine (HMT) for 5HT measurements and $10 \mathrm{ng}$ of dihydroxybenzylamine (DHBA) for catecholamine measurements. After centrifugation at $20000 \times g\left(4{ }^{\circ} \mathrm{C}\right)$ for $10 \mathrm{~min}$, supernatant was neutralized with saturated $\mathrm{K}_{2} \mathrm{CO}_{3}$. After a second centrifugation, super- 
natant was divided into two aliquots for the determination of catecholamines (aliquot A) and serotonin (aliquot B).

\subsection{Monoamine analysis}

All analysis used reversed phase HPLC with electrochemical detection. Catecholamine analysis was performed following a modified method from Maruta et al. (1984). A $1 \mathrm{ml}$ of aliquot A was extracted on activated boric acid gel and catecholamines were desorbed with $0.75 \mathrm{M} \mathrm{CH}_{3} \mathrm{COOH}$. After filtration through $0.45 \mu \mathrm{m}, 50 \mu \mathrm{l}$ of the $\mathrm{CH}_{3} \mathrm{COOH}$ extract was injected into the HPLC system. The HPLC system consisted of a pump (Bio-Tek kontron instruments, model 422) coupled to an electrochemical detector (Bioanalytical Systems, Inc. Model LC-4B). Separation was performed on Ultrasphere ODS column $(150 \times 4.6 \mathrm{~mm}$; I.D, $5 \mu \mathrm{m}$ ). The mobile phase (mobile phase A) was a mixture of 97\% citrate-phosphate buffer (citric acid $35 \mathrm{mM}$ and disodium hydrogen phosphate $12.5 \mathrm{mM})+3 \%$ acetonitrile and $0.34 \mathrm{mM}$ sodium octyl sulfate at $\mathrm{pH} 3.35$. The applied potential was set at $+700 \mathrm{mV}$ for electrochemical detection.

Serotonin analysis was performed following a modified method from Fujimori et al. (1982) using $1 \mathrm{ml}$ of aliquot B to run a double extraction in butanol and heptane. Serotonin was recovered in $0.1 \mathrm{~N} \mathrm{HCL}$, and after filtration on $0.45 \mu \mathrm{m}, 50 \mu \mathrm{l}$ of the HCL extract was injected into the HPLC system. Separation was made on Nucleosil $(150 \times 4.6 \mathrm{~mm}$; ID, $5 \mu \mathrm{m})$. The mobile phase (mobile phase B) consisted of a mixture of $93 \%$ (sodium acetate $0.1 \mathrm{M}$ and glacial acid acetic) $+7 \%$ acetonitrile and $0.21 \mathrm{mM}$ sodium octyl sulfate at $\mathrm{pH}$ 5.0. The applied potential was set at $+700 \mathrm{mV}$ for electrochemical detection.

Monoamines were identified by comparison of their retention times to those of known standards as a function of increasing concentrations of acetonitrile $(2-5 \%$ for catecholamines, 5-9\% for serotonin). Standard curves of peak height as a function of concentration were drawn at the beginning of each series of analysis.

\subsection{Protein analysis}

Larvae and post-larvae were regularly sampled for protein analysis (Fig. 1) and for shell length measurement (Table 1). Animals were counted, washed with $(0.5 \mathrm{M})$ ammonium formate and placed in distilled water. Samples were frozen at $-20^{\circ} \mathrm{C}$. After thawing, they were homogenized with Polytron before analysis.

Total protein was extracted in $1 \mathrm{M} \mathrm{NaOH}$ for $1 \mathrm{~h}$ at ambient temperature, and measured following the method of Lowry et al. (1951) at a wavelength of $660 \mathrm{~nm}$, with an auto-analyzer (Alliance Instruments integral $4^{+}$). The results

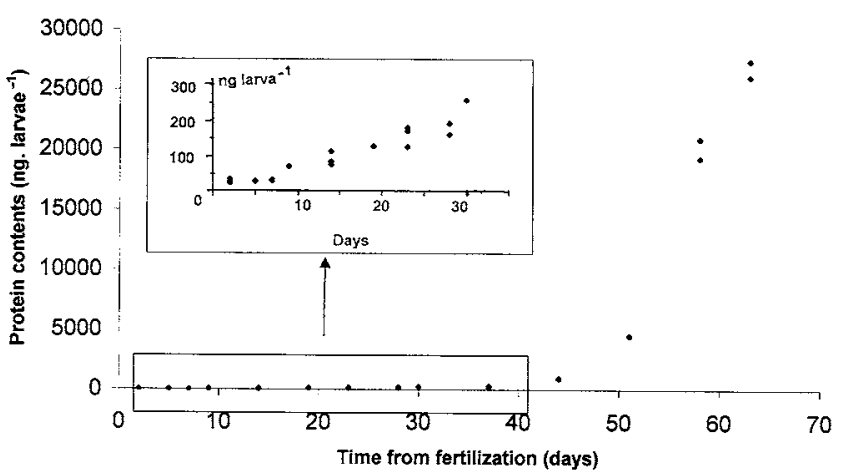

Fig. 1. P. maximus larval and post-larval protein contents (ng per larva) related to the age. Period of metamorphosis: between day 27 and day 34 .

were expressed in ng per larvae. Larval size was determined in a minimum of 50 individuals per tank every second day, by measuring the length by means of image analysis processing as previously described by Pontual et al. (1998).

\section{Results}

Chromatograms obtained for standard mixtures of catecholamines and serotonin are shown in Fig. 2 while those for extracts of P. maximus larvae are represented in Fig. 3. Among the catecholamines, DA was the dominant catecholamine in all larval samples while NE remained at a low level and $\mathrm{E}$ was absent from all larval samples. In these chromatographic conditions, the limit of detection was about $15 \mathrm{pg}$ injected with a ratio signal/noise of 3 . Serotonin was detected at concentrations similar to DA.

Recoveries of the extraction procedure were about $40 \%$ for catecholamines and $80 \%$ for serotonin. These values were calculated with internal standard added during homogenization at the beginning of the extraction procedure.

The monoamine contents in relation to age are reported in Fig. 4. During the first 20 days, the levels of DA, 5HT and NE increased progressively until day 20 in the larvae. Then, between day 20 and day 27, DA and 5HT, respectively, rose from 30 to 50 and 15 to $50 \mathrm{pg} \mathrm{\mu g}^{-1}$ of protein while $\mathrm{NE}$ content remained constant.

In 1-week-old post-larvae (day 2-day 34), DA and 5HT contents declined sharply to levels of $15 \mathrm{pg} \mathrm{\mu g}^{-1}$ of protein, values similar to those obtained in the first days of larval life. From the second week of post-larval life (day 34-day 55) of the post-larval period, monoamine concentrations

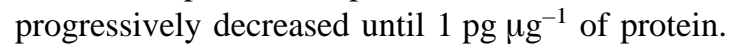

To test the statistical significance of the results, data were pooled in three periods: period 1 corresponding to the larval stage (days $0-17$ ), period 2 to the premetamorphosis stage (days 19-27), and period 3 (days 27-55) to metamorphosis

Table 1

Shell length related to the age of $P$. maximus larvae and post-larvae. Mean \pm S.D.

\begin{tabular}{|c|c|c|c|c|c|c|c|c|c|c|}
\hline Age (days) & 2 & 8 & 13 & 17 & 24 & 27 & 34 & 41 & 48 & 55 \\
\hline Shell Length $(\mu \mathrm{m})$ & $90 \pm 2$ & $140 \pm 7$ & $160 \pm 13$ & $180 \pm 22$ & $230 \pm 25$ & $260 \pm 29$ & $450 \pm 32$ & $700 \pm 34$ & $1100 \pm 37$ & $1500 \pm 40$ \\
\hline
\end{tabular}



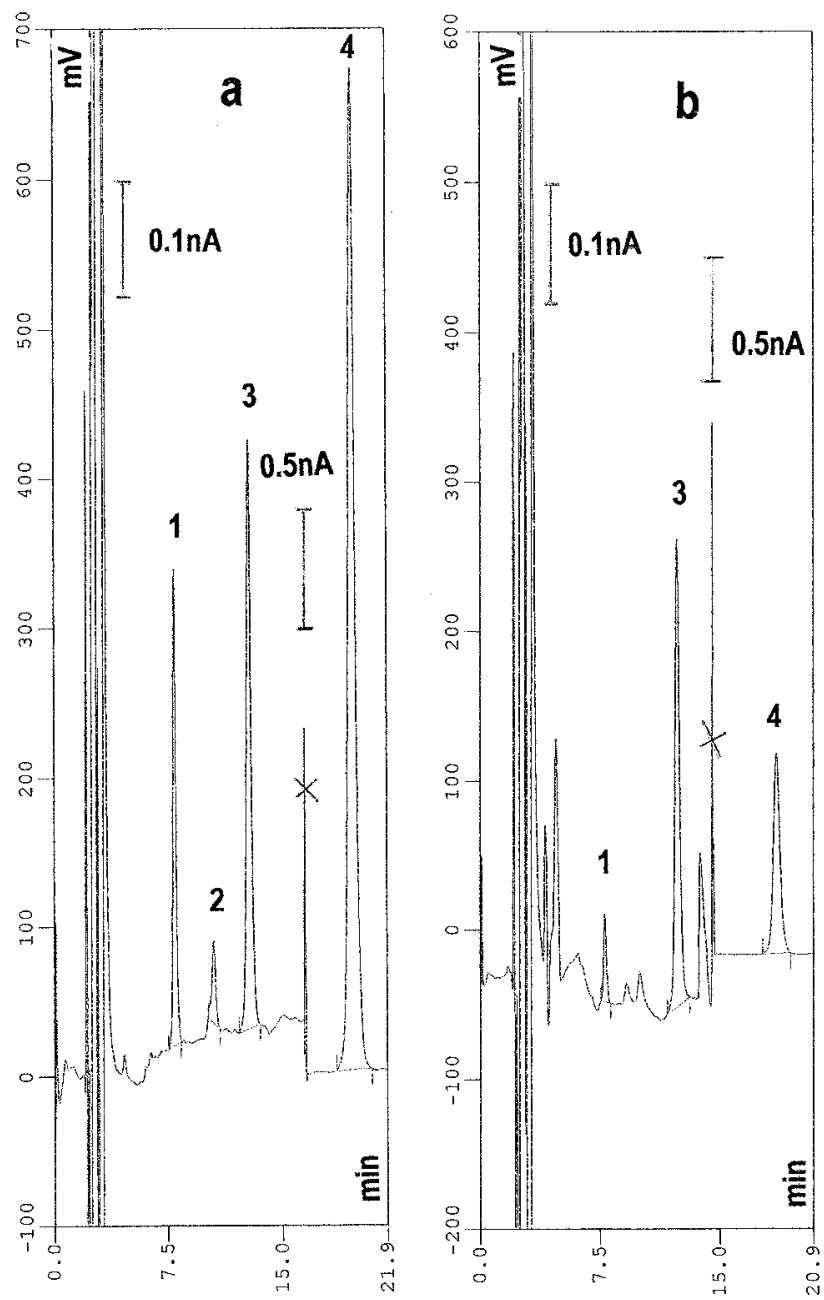

Fig. 2. Separation of catecholamines standard mixture (a) and in P. maximus larvae extract (day 10 from fertilization: b). Amounts injected in ng: 1, norepinephrine (NE, 0.125); 2, epinephrine (E, 0.025); 3, dihydroxybenzoic acid (DHBA, internal standard 0.25); 4, dopamine (DA, 1.005). Chromatographic conditions: ultrasphere ODS $5 \mu \mathrm{m}$ column; flow-rate, $0.8 \mathrm{ml} \mathrm{min}^{-1}$; electrochemical potential, $700 \mathrm{mV}$; mobile phase A. Chromatograms were integrated by the software chromasystem 2000 (Bioteck instruments).

and the post-larval stage. A one-way ANOVA revealed highly significant differences in 5HT $(F 3.42=5.51$; $P<0.01)$ and DA $(F 3.42=13.02 ; P<0.001)$ and no significant difference for NE (Table 2).

\section{Discussion}

DA and 5HT were the most abundant monoamines detected in P. maximus larvae compared to $\mathrm{NE}$ and $\mathrm{E}$ (undetected at any age). These results agree with those obtained in adults of P. maximus (Paulet et al., 1993). Few reports on levels of endogenous monoamines in marine invertebrate larvae have been reported in the literature. Coon and Bonar (1986) have determined the levels of catecholamines in Crassostrea gigas. larvae with DA from
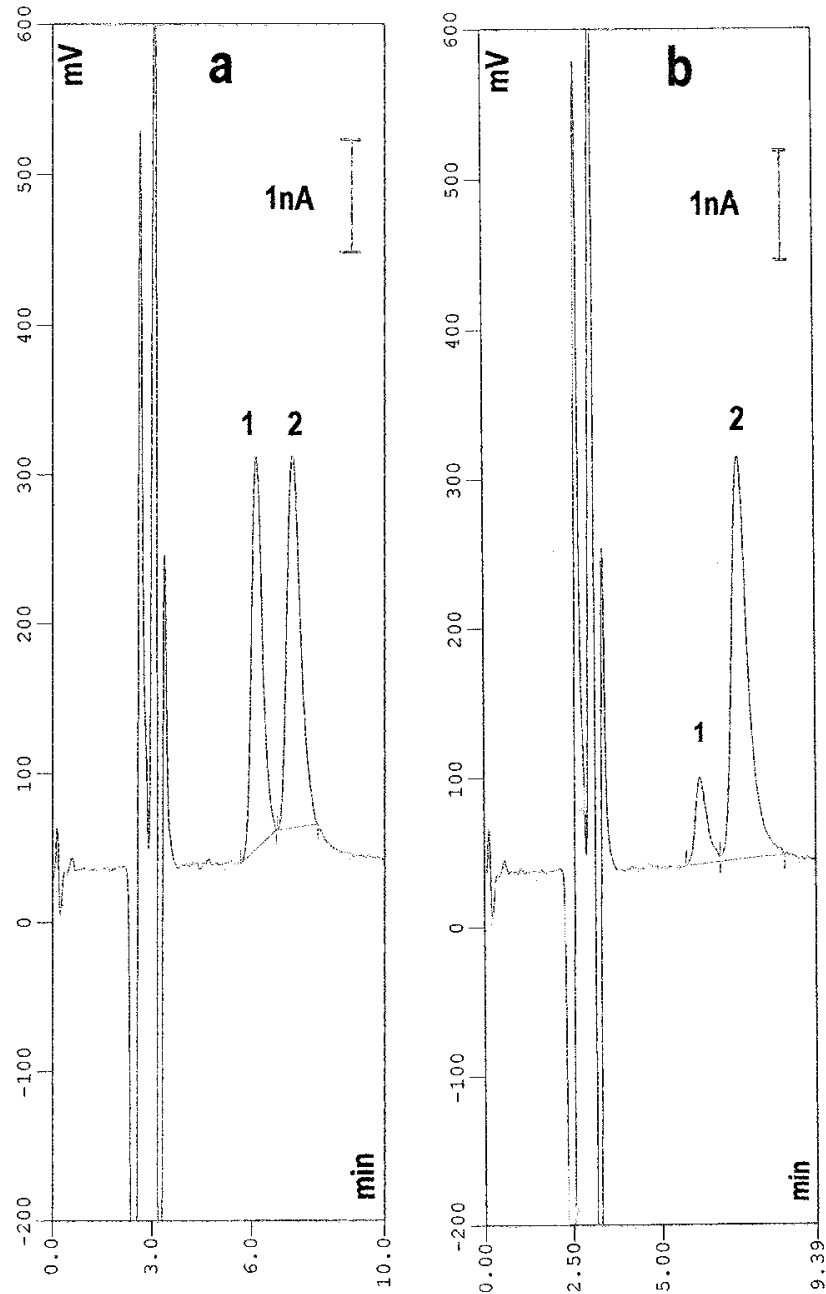

Fig. 3. Separation of indoleamines standard mixture (a) and in P. maximus larvae extract (day 10 from fertilization: b). Amounts injected in ng: 1, serotonin (5HT, 0.5675); 2, 5-hydroxy-methyl-tyramine (5HMT, internal standard 1.25). Chromatographic conditions: Nucleosil ODS $5 \mu \mathrm{m}$ column; flow-rate $0.8 \mathrm{ml} \mathrm{min}{ }^{-1}$; electrochemical potential, $700 \mathrm{mV}$; mobile phase B. Chromatograms were integrated by the software chromasystem 2000 (Bioteck instruments).

7 to $12 \mathrm{pg} \mathrm{g}^{-1}$ of protein, NE from 0.1 to $1 \mathrm{pg} \mathrm{g}^{-1}$ of protein while $\mathrm{E}$ remained at trace levels in all larvae samples. In P. maximus larvae (present study), the contents of DA and $\mathrm{NE}$ are two to five times higher.

Catecholamines and DOPA have also been recently quantified in larvae of the nudibranch Phestilla sibogae (Pires et al., 1997) with DA levels higher than those of DOPA and NE. In the above cited studies, DA appears as a major catecholamine in term of quantity in mollusc larvae but its functional role(s) is not always completely identified.

Concerning the methodological part, the recoveries of the extraction procedures are different for catecholamines $(40 \%)$ and serotonin $(80 \%)$. Such differences can be explained by the method that is quite different. The extraction of catecholamines use a liquid-solid method (numerous steps through a boric acid gel) when the extraction of 


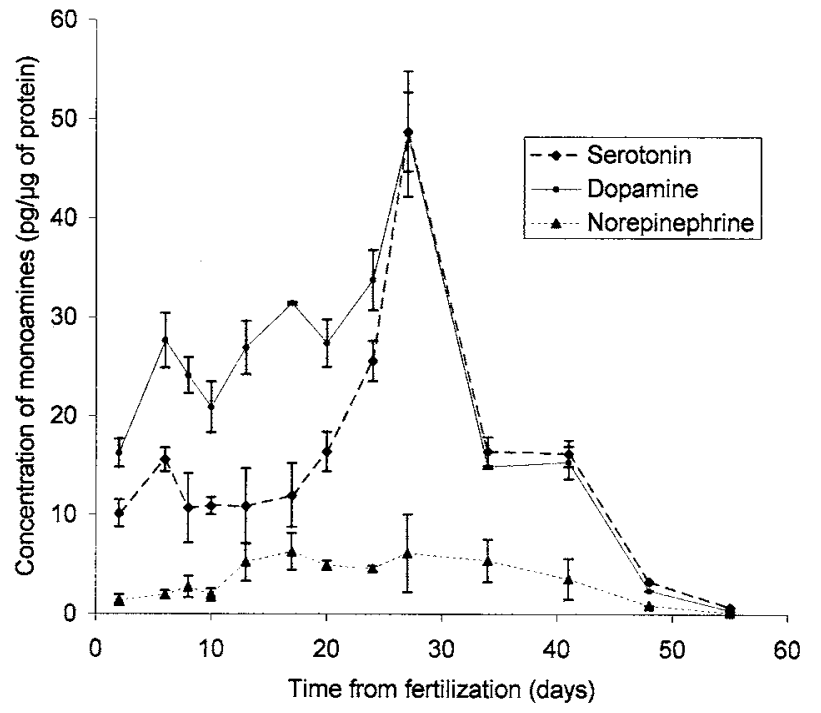

Fig. 4. Profiles of serotonin $(\bullet)$, dopamine $(\bullet)$ and norepinephrine $(\boldsymbol{\Delta})$ during larval and post-larval development of P. maximus. Results are

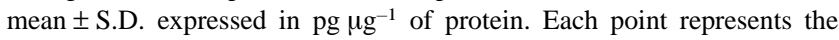
mean content of four to six analysis (three cultures with duplicate samplings). For the correspondence between age and shell length see Table 1. Period of metamorphosis: between day 27 and day 34 .

serotonin needs a more simple liquid-liquid method. On the other hand, the use of the boric acid gel gives a good reproducibility and selectivity, which is in part responsible for the correct resolution of the peaks. The recovery of catecholamines is low in comparison to other studies in bivalves. Indeed Coon and Bonar (1986) found a recovery of $60 \%$ from oyster larvae by using alumina to extract catecholamines. In Pectinidae, Pani and Croll (1995) indicated 70-90\% recovery but in hemolymph, which is largely cleaner than other tissues or whole larvae like in our study.

In the present work, only the contents of DA and 5HT showed significant variation throughout the larval and post-larval development of P. maximus. The main result consists in a marked increase of 5HT and DA in larvae at the approach of metamorphosis followed by a sharp decrease during post-larval life. Monoamines accumulation occurring prior to metamorphosis might be explained as follows. First, the synthetic pathways of monoamines are strongly activated in neurons already present in larvae and/or the catabolic pathways are less active. The quantification of the metabolites of monoamines as 5-hydroxy-3-indoleacetic

\section{Table 2}

Average contents of 5-hydroxy-tryptamine (5HT), dopamine (DA) and norepinephrine $(\mathrm{NE})$ in three distinctive periods of larval and post-larval

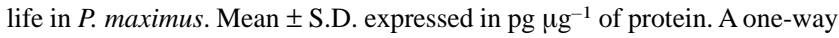
ANOVA was used. Results were significantly different for DA $\left(P<0.001^{* *}\right)$ and 5HT $\left(P<0.01^{*}\right)$. NS: not significant

\begin{tabular}{llll}
\hline & $\begin{array}{l}\text { Period } 1 \\
(0-17 \text { days })\end{array}$ & $\begin{array}{l}\text { Period } 2 \\
(19-27 \text { days })\end{array}$ & $\begin{array}{l}\text { Period 3 } \\
(30-58 \text { days }) \\
n=18\end{array}$ \\
\hline 5HT & $10.2 \pm 3.9^{*}$ & $24.4 \pm 15.3^{*}$ & $11.6 \pm 7.5^{*}$ \\
DA & $19.6 \pm 7.3^{* *}$ & $32.3 \pm 10.0^{* *}$ & $10.5 \pm 7.2^{* *}$ \\
NE & $2.6 \pm 1.8 \mathrm{NS}$ & $4.7 \pm 1.2 \mathrm{NS}$ & $3.2 \pm 2.6 \mathrm{NS}$ \\
\hline
\end{tabular}

acid (5-HIAA) for 5HT or 3,4-dihydroxyphenylacetic acid (DOPAC) and homovanillic acid (HVA) for DA might bring useful information in the future to strengthen this hypothesis. These transient high levels of monoamines might also coincide with a multiplication of monoaminergic neurons necessary for metamorphosis or post-metamorphic physiological functions. Indeed numerous catecholaminergic neurons have been located in the velum, foot, mantle, central nervous system and mouth area of scallop larvae P. magellanicus (Croll et al., 1997) while a clear correlation between maturation of catecholaminergic neurons and development of locomotory and respiratory functions has been set up in the pond snail Lymnaea stagnalis (Croll et al., 1999). In a same manner, serotonin regulate metamorphosis in the marine snail Ilyanassa obsoleta (Leise et al., 2001).

Changes in monoamine contents have been also reported in other invertebrates but differed from our study. Indeed, the DA levels remained constant throughout larval life of C. gigas, while NE increased prior to metamorphosis (Coon and Bonar, 1986). The implication of $\mathrm{NE}$ and/or DA in metamorphic processes is also supported by pharmacological studies suggesting that dopaminergic and adrenergic neural pathways, respectively, mediate natural settlement and metamorphosis in the Japanese oyster (Coon and Bonar, 1987; Bonar et al., 1990) or in the prosobranch gastropod Crepidula fornicata (Pechenik et al., 2002). In the gastropod $P$. sibogae, a recent study showed increase of levels of endogenous catecholamine around the time of competence for metamorphosis (Pires et al., 2000).

These results suggest that catecholamines, as well as 5HT for $P$. maximus, may play a role in metamorphosis processes in molluscs.

From the beginning of metamorphosis (from day 27), there are declines in DA and 5HT content, which might coincide with velar loss. Indeed Kempf et al. (1992) and Croll et al. (1997) have observed that the velum of different molluscs was innervated by catecholaminergic fibers.

Future investigations should be performed to confirm these rapid neurochemical changes around metamorphosis and to verify if endogenous monoamines might be used as a criterion of competence for metamorphosis in $P$. maximus. These results may contribute to a better control behavior and physiology of this commercial species. However, this paper confirms some similarities among the larvae from various invertebrate regarding the change of monoamine contents during the larval and post-larval periods.

\section{Acknowledgements}

Jean-Paul Connan and Michel Mazuret from the hatchery of Argenton provided assistance in culturing microalgae, larvae and postlarvae. We would like also thank MarieLouise Muzelec from the hatchery of Tinduff for providing samples of Pecten maximus post-larvae and Claudie Quéré 
for helping in protein analysis. This research was partially funded by a grant financed by the region of Brittany.

\section{References}

Beiras, R., Widdows, J., 1996. Induction of metamorphosis in larvae of the oyster Crassostrea gigas using neuroactive compounds. Mar. Biol. 123, 327-334.

Bonar, D.B., Coon, S.L., Walch, M., Weiner, R.M., Fitt, W., 1990. Control of oyster settlement and metamorphosis by endogenous and exogenous chemical cues. Bull. Mar. Sci. 46, 484-498.

Chevolot, L., Cochard, J.C., Yvin, J.C., 1991. Chemical induction of larval metamorphosis of Pecten maximus with a note on the nature of naturally occurring triggering substances. Mar. Ecol. Prog. Ser. 74, 83-89.

Coon, S.L., Bonar, D.B., 1985. Induction of settlement and metamorphosis of the Pacific oyster, Crassostrea gigas (Thunberg), by L-DOPA and catecholamines. J. Exp. Mar. Biol. Ecol. 94, 211-221.

Coon, S.L., Bonar, D.B., 1986. Norepinephrine and dopamine content of larvae and spat of the Pacific oyster, Crassostrea gigas. Biol. Bull. 171, 632-639.

Coon, S.L., Bonar, D.B., 1987. Pharmacological evidence that alpha 1 adrenoreceptors mediate metamorphosis of the Pacific oyster Crassostrea gigas. Neuroscience 23, 1169-1174.

Croll, R.P., Jackson, D.L., Voronezhskaya, E.E., 1997. Catecholaminecontaining cells in larval and postlarval bivalve molluscs. Biol. Bull. 193, 116-124.

Croll, R.P., Voronezhskaya, E.E., Hiripi, L., Elekes, K., 1999. Development of catecholaminergic neurons in the pond snail, Lymnaea stagnalis: II. Postembryonic development of central and peripheral cells. J. Comp. Neurol. 404, 297-309.

Fujimori, T., Yamanishi, Y., Yamatsu, K., Tajima, T., 1982. High performance liquid chromatography (HPLC) determination of endogenous serotonin released from aggregating platelets. J. Pharmacol. Methods 7, 105-113.

Kempf, S.C., Chun, G.V., Hadfield, M.G., 1992. An immunocytochemical search for potential neurotransmitters in larvae of Phestilla sibogae (Gastropoda, Opisthobranchia). Comp. Biochem. Physiol. 101C, 299-305.

Kuang, S., Goldberg, J.I., 2001. Laser ablation reveals regulation of ciliary activity by serotonergic neurons in molluscan embryos. J. Neurobiol. 47, 1-15.

Leise, E.M., Thavaradhara, K., Durham, N.R., Turner, B.E., 2001. Serotonin and nitric oxide regulate metamorphosis in the marine snail Ilyanassa obsoleta. Am. Zool. 41, 258-267.

Lowry, O.H., Rosebrough, N.J., Farr, A.L., Randall, R.G., 1951. Protein measurement with the Folin phenol reagent. J. Biol. Chem. 193, 265-275.

Martinez, G., Saleh, F., Mettifogo, L., Campos, E., Inestrosa, N., 1996. Monoamines and the release of gametes by the scallop Argopecten purpuratus. J. Exp. Zool. 274, 365-372.

Maruta, K., Fujita, K., Ito, S., Nagatsu, T., 1984. Liquid chromatography of catecholamines, with electrochemical detection, after treatment with boric acid gel. Clin. Chem. 30, 1271-1273.
Nicolas, L., Robert, R., 2001. The effect of food supply on metamorphosis and post-larval development in hatchery-reared, Pecten maximus. Aquaculture 192, 347-359.

Nicolas, L., Robert, R., Chevolot, L., 1998. Comparative effect of inducers on metamorphosis of the Japanese oyster Crassostrea gigas and the great scallop, Pecten maximus. Biofouling 12, 189-203.

Osada, M., Matsutani, T., Nomura, T., 1987. Implication of catecholamines during spawning in marine bivalve molluscs. Int. J. Invertebr. Reprod. Dev. 12, 241-252.

Pani, A.K., Croll, R.P., 1995. Distribution of catecholamines, indoleamines, and their precursors and metabolites in the scallop, Placopecten magellanicus (Bivalvia, Pectinidae). Cell. Mol. Neurobiol. 15, 371-386.

Pani, A.K., Croll, R.P., 2000. Catechol concentrations in the hemolymph of the scallop, Placopecten magellanicus. Gen. Comp. Endocrinol. 118, $48-56$.

Paulet, Y.M., Donval, A., Bekhadra, F., 1993. Monoamines and reproduction in Pecten maximus, a preliminary approach. Invertebr. Reprod. Dev. 23, 89-94.

Pechenik, J.A., Li, W., Cochrane, D.E., 2002. Timing is everything: the effects of putative dopamine antagonists on metamorphosis vary with larval age and experimental duration in the prosobranch gastropod Crepidula fornicata. Biol. Bull. 202, 137-147.

Pires, A., Coon, S.L., Hadfield, M.G., 1997. Catecholamines and dihydroxyphenylalanine in metamorphosing larvae of the nudibranch Phestilla sibogae Bergh (Gastropoda: Opistobranchia). J. Comp. Physiol. A. 181, 187-194.

Pires, A., Croll, R.P., Hadfield, M.G., 2000. Catecholamines modulate metamorphosis in the opisthobranch gastropod Phestilla sibogae. Biol. Bull. 198, 319-331.

Pontual (de), H., Robert, R., Miner, P., 1998. Study of bivalve larval growth using image processing. Aquac. Eng. 17, 94-95.

Robert, R., Gérard, A., 1999. Bivalve hatchery technology: the current situation for the Pacific oyster Crassostrea gigas and the scallop Pecten maximus in France. Aquat. Living Resour. 12, 121-130.

Robert, R., Nicolas, L., Moisan, C., Barbier, G., 1999. Morphological and biochemical characterizations of the great scallop Pecten maximus metamorphosis. CR Acad. Sci. III 322, 847-853.

Shpigel, M., Coon, S.L., Kleinot, P., 1989. Growth and survival of cultchless spat of Ostrea edulis Linnaeus, 1750 produced using epinephrine and shell chips. J. Shellfish Res. 8, 355-357.

Smith, S.A., Nason, J., Croll, R.P., 1998. Distribution of catecholamines in the sea scallop, Placopecten magellanicus. Can. J. Zool. 76, $1254-1262$.

Weiner, N., Molinoff, P.B., 1989. Catecholamines. In: Siegel, G., Agranof, B., Albers, R.W., Molinoff, P. (Eds.), Basic Neurochemistry. Raven press, New York, pp. 233-251.

Yvin, J.C., Chevolot, L., Chevolot-Magueur, L., Cochard, J.C., 1985. First isolation of jacaranone from an alga Delesseria sanguinea: a metamorphosis inducer of Pecten larvae. J. Nat. Prod. 48, 814-816. 